American Journal of Pharmaceutical Education 2017; 81 (6) Article 108.

\title{
RESEARCH
}

\section{First-year Student Pharmacists' Spirituality and Perceptions Regarding the Role of Spirituality in Pharmacy Education}

\author{
Bobby Jacob, PharmD, ${ }^{\mathrm{a}}$ Annesha White, PharmD, PhD, MS, ${ }^{\mathrm{b}}$ Angela Shogbon, PharmD ${ }^{\mathrm{a}}$ \\ ${ }^{a}$ Mercer University College of Pharmacy, Atlanta, Georgia \\ ${ }^{\mathrm{b}}$ University of North Texas System College of Pharmacy, Fort Worth, Texas
}

Submitted May 27, 2016; accepted December 18, 2016; published August 2017.

Objective: To measure student pharmacists' spirituality utilizing validated survey instruments and to determine perceptions regarding the anticipated role of spirituality in academic course work and professional practice.

Methods: This was a cross-sectional, descriptive study. The survey was offered to all first-year student pharmacists during the first week of the fall semester (2012-2015). Descriptive and inferential statistics were used to analyze data.

Results: A total of 580 students (98\%) participated. The majority of students reported having each of the spiritual experiences on most days of the week or more frequently (58\% to $89 \%$ based on individual item). Furthermore, $57 \%$ of students anticipate that matters of spirituality would be significant components of academic course work and $75 \%$ anticipate they would be incorporated into eventual professional practice settings. These perceptions were positively correlated to measures of spirituality and religiosity.

Conclusion: These findings suggest that faculty should evaluate current and future incorporation of topics related to spirituality and health in pharmacy curriculum.

Keywords: spirituality, religiosity, student pharmacist

\section{INTRODUCTION}

There has been a resurgence of interest in the role of spirituality in health care. ${ }^{1-4}$ The medical community is recognizing the significant implications for patients when spirituality and health care intersect such as it relates to influence on health care decision making, religious beliefs that conflict with medical care, spiritual struggles that impair health outcomes, and disease detection. ${ }^{5}$ The Association of American Medical Colleges affirms that spirituality is a recognized factor that contributes to health in many patients, and that it can influence the way patients and health care providers interact with each other. ${ }^{6}$ Elective courses on spirituality and health care in schools of medicine and nursing have included content related to teaching students to take spiritual assessments, evaluation of published literature on spirituality in health care, reviewing cases that include patients' spiritual histories, learning to communicate with patients facing chronic illness or endof-life decisions, and teaching students to reflect on their

Corresponding Author: Bobby Jacob, Mercer University College of Pharmacy, 3001 Mercer University Drive, Atlanta, GA 30341. Tel: 678-547-6307. E-mail: Jacob_bc@mercer.edu own belief systems and the influence these may have on provision of health care. $^{7-9}$

Pedagogical literature examining the role of spirituality as a component of pharmacy education is quite limited. Cooper and colleagues in 2003 conducted a survey-based study of 94 accredited colleges of pharmacy in the United States and Canada that was designed to examine the extent of spiritual care incorporated in the curriculums. ${ }^{10}$ Findings revealed that spiritual aspects of patient care were addressed in only $21 \%$ of pharmacy curriculums, with only $10 \%$ of these being in a required course. Faculty and student leaders expressed the belief that spiritual aspects of patient care fell into the scope of pharmacy practice. Furthermore, $80 \%$ of student leaders felt that incorporation of the topic in some form would be beneficial for students' professional development.

Dugan and colleagues in 2011 described the design and implementation of an elective course for pharmacy students at a private, Christian university that examined the relationship between spirituality and health care. ${ }^{11}$ The course consisted of didactic lectures and facilitated discussions on various general principles related to spirituality in health care, assigned tertiary and primary literature readings, obtaining spiritual histories, presenting 


\section{American Journal of Pharmaceutical Education 2017; 81 (6) Article 108.}

primary literature study evaluations, and reflective journal writing. Campbell and Briton described an elective course offered jointly to 13 student pharmacists and seven medical students at a large public university. ${ }^{12}$ A survey at the end of this course indicated that the majority of students felt comfortable addressing issues of spirituality in the context of providing patient care. To date, no studies have been published that specifically evaluate measures of spirituality among student pharmacists or determine student pharmacists' perceptions regarding the role of spirituality in pharmacy education and practice.

The objective of this study was to measure spirituality among entering student pharmacists utilizing validated survey instruments and to determine student pharmacists' perceptions regarding the role of spirituality in the doctor of pharmacy curriculum and eventual professional practice. A secondary objective was to examine the relationship between students' perceptions regarding the role of spirituality in pharmacy education and objective measures of spirituality.

\section{METHODS}

This was a four-year, cross-sectional, descriptive study with an electronic survey design. The authors received permission to include the Daily Spiritual Experience Scale (DSES) and the Duke Religion Index (DUREL) in the survey. These two instruments are validated and have been used extensively in settings outside of pharmacy education. The DSES originally was designed for use in health care and has been incorporated into studies published by various academic disciplines in health and social sciences. ${ }^{13}$ The DSES contains 16 items designed to measure ordinary daily spiritual experiences, while being inclusive of individuals with diverse theistic or non-theistic beliefs. The first 15 items of the DSES ask respondents to rate the frequency of various spiritual experiences using six response choices, ranging from "many times a day" to "never or almost never." The final question asks respondents to self-assess their own perceived closeness to God or what they consider as divine using four response choices ranging from "as close as possible" to "not close at all." The scale includes instructions to the participant stating that if they are not comfortable with the use of the word God, they may substitute another word that is more appropriate for their spiritual beliefs. The DUREL is a five-item scale that was designed to be a measure of spirituality and religiosity in epidemiological studies. ${ }^{14}$ The instrument measures organizational, non-organizational, and intrinsic religiosity. Two questions ask respondents to rate the frequency of participation in various religious activities using six response choices ranging from "more than once a week" to "never." For the remaining three items, respondents indicate the extent to which a statement about religious beliefs or experience describes them using five response choices ranging from "definitely true of me" to "definitely not true of me."

In addition to these validated scales, the investigators developed five additional questions to evaluate students' perceptions regarding the anticipated role of spirituality in pharmacy education and eventual professional practice settings (SPE). These questions addressed the impact of personal spirituality on the decision to pursue a career in pharmacy, anticipated role of spirituality in academic course work and eventual practice settings, and perceptions regarding the importance of understanding spirituality as a means of improving the ability to function successfully as a pharmacist. A 4-point Likert scale was provided (strongly agree, agree, disagree, strongly disagree) for these internally developed questions. The authors did not provide a specific definition of spirituality for participants to ensure that the study remained as open and inclusive as possible and to encourage the maximum amount of student participation.

The complete survey instrument was offered to all entering first-year student pharmacists at Mercer University during the first week of the fall semester from 2012 to 2015. Mercer University, located in the southeastern United States, is a private institution for higher education. The university has no formal affiliation with any denomination and maintains a strong embrace of intellectual and religious freedom. First-year student pharmacists were chosen as the sample population to establish a baseline for a planned future longitudinal evaluation of changes in students' spirituality and perceptions during enrollment in pharmacy school. The survey was prepared using a data collection and analysis software program designed by Qualtrics (Qualtrics Labs, Provo, UT). Students received an electronic link to the survey and were given approximately 15 minutes during in-class orientation to complete the survey. Students were asked to complete the survey during the time provided during orientation. Participation in the study was voluntary, and informed consent was obtained from all participants. Institutional Review Board approval was obtained from Mercer University.

Descriptive statistics were utilized for questionnaire items, and qualitative data from questionnaires were content analyzed. Pearson $r$ correlation coefficients were calculated for the DSES, DUREL, and the internally developed questionnaire (SPE). Correlations were examined to determine whether a relationship existed between students' spirituality as indicated by the DSES or DUREL and students' perceptions on the role of spirituality in 


\section{American Journal of Pharmaceutical Education 2017; 81 (6) Article 108.}

education as indicated by responses to the SPE. Additionally, Pearson $r$ correlation coefficients were determined to examine the relationship of religious affiliation and the SPE. The a priori level of statistical significance was $p<.05$. Statistical evaluation was completed using IBM SPSS Statistics Version 21.0 (IBM Corp., Armonk, NY).

\section{RESULTS}

A total of 580 student pharmacists participated in the study (98\% response rate) including 146 students in 2012, 148 students in 2013, 132 students in 2014, and 154 students in 2015. Overall, the majority of participants were female $(66 \%)$ and between the ages of 21 and 30 years $(88 \%)$. Religious affiliations among students included Christian (70\%), Hindu (7\%), Buddhist (5\%), Muslim (3\%), Jewish $(1 \%)$, and other $(3 \%)$. Twelve percent of students indicated no preference in terms of religious affiliation. The participants in the survey were racially and ethnically diverse (white $43 \%$, Asian 33\%, black 21\%, Hispanic 4\%, American Indian 1\%, and native Hawaiian/Pacific Islander 1\%), which is consistent with the racial and ethnic demographic make-up of the college of pharmacy.

Measures of spirituality from each of the four years as assessed by the DSES and DUREL are presented in Tables 1 and 2, respectively. The most common spiritual experiences for students included feeling thankful for personal blessings, feeling a selfless caring for others, and accepting others even when feeling they are wrong. Likewise, $68 \%$ of students reported experiencing the divine in their life and $58 \%$ of students reported incorporating religious beliefs into all other aspects of their life. Furthermore, $48 \%$ of participants considered themselves to be very close or as close as possible to God, and $31 \%$ reported attending religious meetings once a week or more.

Student pharmacists' perceptions on the role of spirituality in pharmacy education and professional practice are shown in Table 3. Students believed that matters of spirituality would be significant components of academic course work in the doctor of pharmacy program (57\%), while an even greater percentage of students anticipated that matters of spirituality would be incorporated or integrated into their eventual professional practice setting (75\%). Student perceptions regarding the role of spirituality in pharmacy education and professional practice were significantly correlated to all items from the DSES and DUREL (Table 4 and 5). Students who indicated a religious affiliation were more likely than those without any specific religious association to anticipate a role for spirituality in academic course work $(60 \%$ vs $28 \%, p<.001)$ and professional pharmacy practice $(79 \%$ vs $44 \%$, $p<.001)$. In addition, the almost nine out of ten students believed that having a general understanding of the role of spirituality in society was useful in order to be fully

Table 1. Daily Spiritual Experiences Scale ${ }^{\mathrm{a}, 13}$

\begin{tabular}{|c|c|c|c|c|c|}
\hline \multirow[b]{2}{*}{ Statement } & \multicolumn{5}{|c|}{$\%$ of class } \\
\hline & $\begin{array}{c}2012 \\
(n=146)\end{array}$ & $\begin{array}{c}2013 \\
(\mathrm{n}=148)\end{array}$ & $\begin{array}{c}2014 \\
(n=132)\end{array}$ & $\begin{array}{c}2015 \\
(n=154)\end{array}$ & $\begin{array}{c}\text { Total } \\
(\mathbf{N}=\mathbf{5 8 0})\end{array}$ \\
\hline I feel God's presence & 66 & 67 & 55 & 64 & 63 \\
\hline I experience a connection to all of life & 74 & 70 & 65 & 68 & 69 \\
\hline $\begin{array}{l}\text { During worship, or at other times when reconnecting with } \\
\text { God, I feel joy which lifts me out of my daily concerns }\end{array}$ & 64 & 64 & 58 & 61 & 62 \\
\hline I find strength in my religion or spirituality & 70 & 73 & 65 & 69 & 69 \\
\hline I find comfort in my religion or spirituality & 77 & 73 & 70 & 72 & 73 \\
\hline I feel deep inner peace or harmony & 69 & 72 & 67 & 71 & 70 \\
\hline I ask for God's help in the midst of daily activities & 61 & 60 & 57 & 62 & 60 \\
\hline I feel guided by God in the midst of daily activities & 60 & 58 & 55 & 61 & 58 \\
\hline I feel God's love for me directly & 68 & 65 & 59 & 67 & 65 \\
\hline I feel God's love for me through others & 71 & 71 & 61 & 65 & 66 \\
\hline I am spiritually touched by the beauty of creation & 75 & 75 & 69 & 69 & 72 \\
\hline I feel thankful for my blessings & 93 & 88 & 86 & 89 & 89 \\
\hline I feel a selfless caring for others & 83 & 82 & 85 & 85 & 84 \\
\hline I accept others even when I think they are wrong & 80 & 82 & 77 & 86 & 81 \\
\hline I desire to be closer to God or in union with the Divine & 73 & 70 & 66 & 69 & 70 \\
\hline In general, how close do you feel to God? ${ }^{\mathrm{b}}$ & 49 & 50 & 40 & 53 & 48 \\
\hline
\end{tabular}

${ }^{a}$ Students were asked to read the first 15 statements and indicate the frequency at which they experienced each of the items listed. Indicates the percentage of students who selected either many times per day, every day, or most days

${ }^{\mathrm{b}}$ Indicates the percentage of students that answered very close or as close as possible 


\section{American Journal of Pharmaceutical Education 2017; 81 (6) Article 108.}

Table 2. Duke Religion Index ${ }^{14}$

\begin{tabular}{|c|c|c|c|c|c|}
\hline \multirow[b]{2}{*}{ Statement } & \multicolumn{5}{|c|}{$\%$ of class } \\
\hline & $\begin{array}{c}2012 \\
(n=146)\end{array}$ & $\begin{array}{c}2013 \\
(n=148)\end{array}$ & $\begin{array}{c}2014 \\
(n=132)\end{array}$ & $\begin{array}{c}2015 \\
(n=154)\end{array}$ & $\begin{array}{c}\text { Total } \\
(\mathbf{N}=\mathbf{5 8 0})\end{array}$ \\
\hline $\begin{array}{l}\text { My religious beliefs are what really lie behind my whole } \\
\text { approach to life }^{\text {a }}\end{array}$ & 63 & 71 & 67 & 64 & 66 \\
\hline $\begin{array}{l}\text { I try hard to carry my religion over into all other dealings in } \\
\text { my life }\end{array}$ & 57 & 62 & 59 & 56 & 58 \\
\hline I attend church or other religious meetings once a week or more ${ }^{b}$ & 36 & 29 & 31 & 32 & 31 \\
\hline $\begin{array}{l}\text { I engage in private religious activities such as prayer, meditation, } \\
\text { or Scripture reading once a week or more }\end{array}$ & 46 & 50 & 42 & 45 & 46 \\
\hline
\end{tabular}

andicates the percentage of students who selected definitely true of me or tends to be true of me in response to the statement

${ }^{b}$ Indicates the percentage of students who selected a frequency of once a week or more than once a week in response to the statement

prepared for a successful career as a pharmacist (89\%). This perspective was shared by students with a selfreported religious affiliation $(90 \%$ agreed or strongly agreed) and those without any specific religious association ( $80 \%$ agreed or strongly agreed).

\section{DISCUSSION}

This study adds to the limited pedagogical literature on spirituality and pharmacy education. This is the first study to evaluate entering student pharmacists' perceptions regarding the anticipated role of spirituality in academic course work related to the doctor of pharmacy curriculum and in eventual professional practice. Strengths of the evaluation include a large, racially and ethnically representative sample population, multiple cohorts, and the incorporation of validated scales to objectively measure spirituality in a manner inclusive of the diverse opinions found in society. Students' perceptions regarding spirituality and pharmacy education were positively correlated to validated measures of spirituality. These findings demonstrate that student pharmacists at this institution, and particularly those with relatively higher self-reported spiritual engagement as assessed by the DSES, enter the profession already recognizing a role for pharmacists in discussing spirituality in the context of their professional practice. All students, irrespective of self-reported religious affiliation, had an appreciation for the importance of understanding the role of spirituality in society to have a successful career as a pharmacist. This study can be implemented at other institutions to determine if there are comparable findings across a broader geographic region relative to student pharmacists' spirituality and perceptions regarding the role of spirituality in pharmacy education.

Interestingly, most students in this sample express relatively higher degrees of spiritual engagement as compared to the general public. For example, the percentage of individuals from the general public experiencing the items measured by the DSES on most days per week or more ranged from $11 \%$ to $44 \%$ compared with our sample, which demonstrated a range of $58 \%$ to $89 \% .{ }^{15}$ Several specific

Table 3. Students' Perceptions Regarding Spirituality and Education ${ }^{\mathrm{a}}$

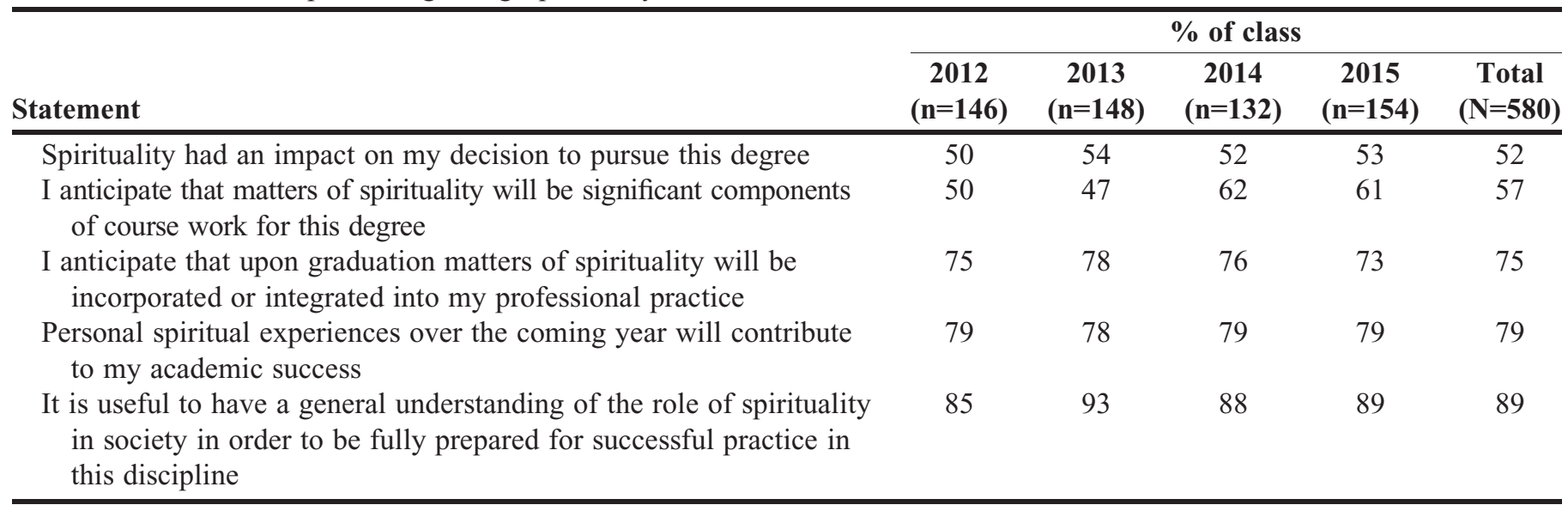

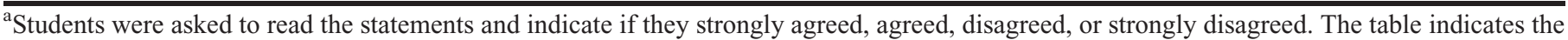
percentage of students who agreed or strongly agreed with the statement 


\section{American Journal of Pharmaceutical Education 2017; 81 (6) Article 108.}

Table 4. Pearson Correlation Coefficients Between the Daily Spiritual Experience Scale (DSES) and the Spirituality in Pharmacy Education (SPE) Questions $(\mathrm{N}=580)^{\mathrm{a}}$

\begin{tabular}{|c|c|c|c|c|c|}
\hline \multirow[b]{2}{*}{$\begin{array}{l}\text { Daily Spiritual } \\
\text { Experience Scale } \\
\text { (DSES) Variable }\end{array}$} & \multicolumn{5}{|c|}{ Spirituality in Pharmacy Education (SPE) Variable } \\
\hline & $\begin{array}{l}\text { Spirituality } \\
\text { had an } \\
\text { impact on } \\
\text { my decision } \\
\text { to pursue } \\
\text { this degree }\end{array}$ & $\begin{array}{c}\text { I anticipate } \\
\text { that matters } \\
\text { of spirituality } \\
\text { will be } \\
\text { significant } \\
\text { components of } \\
\text { course work } \\
\text { for this degree }\end{array}$ & $\begin{array}{c}\text { I anticipate } \\
\text { that upon } \\
\text { graduation, } \\
\text { matters of } \\
\text { spirituality will } \\
\text { be incorporated } \\
\text { or integrated } \\
\text { into my } \\
\text { professional } \\
\text { practice }\end{array}$ & $\begin{array}{l}\text { Personal } \\
\text { spiritual } \\
\text { experiences } \\
\text { over the } \\
\text { coming } \\
\text { year will } \\
\text { contribute } \\
\text { to my } \\
\text { academic } \\
\text { success }\end{array}$ & $\begin{array}{l}\text { It is useful to } \\
\text { have a general } \\
\text { understanding } \\
\text { of the role of } \\
\text { spirituality in } \\
\text { society in order } \\
\text { to be fully } \\
\text { prepared for } \\
\text { successful practice } \\
\text { in my discipline }\end{array}$ \\
\hline I feel God's presence & .53 & .46 & .53 & .63 & .38 \\
\hline $\begin{array}{l}\text { I experience a connection } \\
\text { to all of life }\end{array}$ & .33 & .27 & .34 & .35 & .27 \\
\hline $\begin{array}{l}\text { During worship or at } \\
\text { other times when } \\
\text { connecting to God, } \\
\text { I feel joy which lifts } \\
\text { me out of my } \\
\text { daily concerns }\end{array}$ & .55 & .47 & .51 & .62 & .38 \\
\hline $\begin{array}{l}\text { I find strength in my } \\
\text { religion or spirituality }\end{array}$ & .59 & .48 & .55 & .66 & .40 \\
\hline $\begin{array}{l}\text { I find comfort in my } \\
\text { religion or spirituality }\end{array}$ & .57 & .46 & .53 & .64 & .38 \\
\hline $\begin{array}{l}\text { I feel deep inner peace } \\
\text { or harmony }\end{array}$ & .37 & .30 & .33 & .40 & .27 \\
\hline $\begin{array}{l}\text { I ask for God's help in } \\
\text { the midst of daily } \\
\text { activities }\end{array}$ & .54 & .46 & .50 & .62 & .35 \\
\hline $\begin{array}{l}\text { I feel guided by God in } \\
\text { the midst of daily } \\
\text { activities }\end{array}$ & .55 & .48 & .51 & .64 & .37 \\
\hline $\begin{array}{l}\text { I feel God's love for } \\
\text { me directly }\end{array}$ & .56 & .47 & .54 & .63 & .38 \\
\hline $\begin{array}{l}\text { I feel God's love for } \\
\text { me through others }\end{array}$ & .50 & .43 & .49 & .58 & .38 \\
\hline $\begin{array}{l}\text { I am spiritually touched } \\
\text { by the beauty of } \\
\text { creation }\end{array}$ & .45 & .38 & .46 & .52 & .37 \\
\hline $\begin{array}{l}\text { I feel thankful for my } \\
\text { blessings }\end{array}$ & .36 & .33 & .40 & .47 & .31 \\
\hline $\begin{array}{l}\text { I feel a selfless caring } \\
\text { for others }\end{array}$ & .22 & .23 & .26 & .27 & .26 \\
\hline $\begin{array}{l}\text { I accept others even when } \\
\text { they do things I think } \\
\text { are wrong }\end{array}$ & .16 & .17 & .19 & .20 & .25 \\
\hline $\begin{array}{l}\text { I desire to be closer to } \\
\text { God or in union with } \\
\text { the divine }\end{array}$ & .55 & .49 & .55 & .65 & .39 \\
\hline $\begin{array}{l}\text { In general, how close do } \\
\text { you feel to God? }\end{array}$ & .50 & .41 & .46 & .55 & .33 \\
\hline
\end{tabular}

${ }^{a}$ All correlations are statistically significant $p<.01$ 


\section{American Journal of Pharmaceutical Education 2017; 81 (6) Article 108.}

Table 5. Pearson Correlation Coefficients Between the Duke Religion Index (DUREL) and the Spirituality in Pharmacy Education (SPE) Questions $(\mathrm{N}=580)^{\mathrm{a}}$

\begin{tabular}{|c|c|c|c|c|c|}
\hline \multirow[b]{2}{*}{$\begin{array}{l}\text { Duke Religion } \\
\text { Index (DUREL) } \\
\text { Variable }\end{array}$} & \multicolumn{5}{|c|}{ Spirituality in Pharmacy Education (SPE) Variable } \\
\hline & $\begin{array}{l}\text { Spirituality } \\
\text { had an } \\
\text { impact on } \\
\text { my decision } \\
\text { to pursue } \\
\text { this degree }\end{array}$ & $\begin{array}{c}\text { I anticipate } \\
\text { that matters } \\
\text { of spirituality } \\
\text { will be } \\
\text { significant } \\
\text { components } \\
\text { of course work } \\
\text { for this degree }\end{array}$ & $\begin{array}{l}\text { I anticipate that } \\
\text { upon graduation, } \\
\text { matters of } \\
\text { spirituality } \\
\text { will be } \\
\text { incorporated or } \\
\text { integrated into } \\
\text { my professional } \\
\text { practice }\end{array}$ & $\begin{array}{l}\text { Personal } \\
\text { spiritual } \\
\text { experiences } \\
\text { over the } \\
\text { coming } \\
\text { year will } \\
\text { contribute to } \\
\text { my academic } \\
\text { success }\end{array}$ & $\begin{array}{c}\text { It is useful to } \\
\text { have a general } \\
\text { understanding of } \\
\text { the role of } \\
\text { spirituality in } \\
\text { society in order } \\
\text { to be fully } \\
\text { prepared for } \\
\text { successful practice } \\
\text { in my discipline }\end{array}$ \\
\hline $\begin{array}{l}\text { How often do you attend } \\
\text { church or other } \\
\text { religious meetings? }\end{array}$ & .53 & .44 & .50 & .52 & .33 \\
\hline $\begin{array}{l}\text { How often do you spend } \\
\text { time in private religious } \\
\text { activities, such as prayer, } \\
\text { meditation, or Bible study? }\end{array}$ & .54 & .44 & .52 & .57 & .34 \\
\hline $\begin{array}{l}\text { In my life, I experience the } \\
\text { presence of the Divine }\end{array}$ & .59 & .49 & .57 & .65 & .36 \\
\hline $\begin{array}{l}\text { My religious beliefs are } \\
\text { what really lie behind my } \\
\text { whole approach to life }\end{array}$ & .60 & .48 & .56 & .64 & .39 \\
\hline $\begin{array}{l}\text { I try hard to carry my } \\
\text { religion over into all other } \\
\text { dealings in my life }\end{array}$ & .62 & .50 & .56 & .64 & .39 \\
\hline
\end{tabular}

${ }^{a}$ All correlations are statistically significant $p<.01$

measures were dramatically higher in this student population compared with the general public, such as feeling thankful for blessings most days per week or more $(89 \%$ vs $11 \%$ ) and feeling a selfless caring for others most days per week or more $(84 \%$ vs $29 \%)$. This may suggest that certain attributes related to spirituality have predictive value regarding entrance into the pharmacy profession. An earlier study of 54 student pharmacist leaders found that $80 \%$ believed there was a benefit to learning about the spiritual aspects of patient care, and 90\% were interested in addressing religious beliefs as it related to provision of health care. ${ }^{10}$ This study of a larger sample population, albeit at a single college of pharmacy, seems to echo these results.

Only a few publications have specifically examined the potential role of the pharmacist in providing spiritual care to patients in the context of usual health care responsibilities. ${ }^{16,17}$ These authors suggest positive benefits for patients and caregivers associated with pharmacist initiated spiritual care. Increasingly, financial reimbursement for health care services will be tied to measures such as patient-reported outcomes and quality of care metrics. There may be value in determining if preparing student pharmacists to understand the role of spirituality in health care has the potential to translate to delivery of higher quality and more effective patient care.

It is unclear whether pharmacy school curriculums adequately and effectively prepare student pharmacists to be proficient and comfortable with spiritual aspects of care that might arise in practice. Only a limited number of publications have described curricular approaches to incorporating these topics into academic course work in doctor of pharmacy programs. ${ }^{11,12}$ The Center for Advancement of Pharmacy Education (CAPE) 2013 outcomes emphasize the inclusion of the affective domain as a vital component of developing pharmacists who have the professional skills and personal attributes to support successful patient care roles. ${ }^{18}$ An understanding of how spirituality affects patient's views on health may be an important consideration in developing a student pharmacist who can demonstrate these core competencies. For example, an appreciation for the relationship between spirituality and health care decision-making may encourage student pharmacists to be sensitive and more actively listen to patients when participating in health care initiatives, communicate persuasively regarding specific medication interventions such as oral contraceptives or 


\section{American Journal of Pharmaceutical Education 2017; 81 (6) Article 108.}

analgesics during end-of-life care that have implications related to religious beliefs, and demonstrate empathy when dealing with the diverse population of patients encountered in the United States health care system.

Other implications for curricular consideration of spirituality in pharmacy education include potential influences on development of professionalism and cultural sensitivity. Hammer and colleagues described several components of professionalism such as altruism, honor, integrity, respect for others, advocacy, and caring that have deep roots in spiritual and religious thought. ${ }^{19}$ Some elective courses at pharmacy schools have begun to incorporate discussions related to spirituality as one aspect of developing a culturally competent student pharmacist. ${ }^{20,21}$

There are several limitations to this study. First, the data are from students at a single, private institution of higher education located in a specific geographic area. There are cultural values and socioeconomic demographics unique to this region that distinguish it from other geographic regions in the country and world, which may affect generalizability of the results. Further research is warranted and can be undertaken to examine these questions in a more geographically diverse sample of student pharmacists. The study population included a relatively high percentage of students affiliated with the Christian faith; however, overall religious affiliation in the student population was generally similar to published data from the Pew Research Center on the United States general population. ${ }^{22}$ The low number of students with non-Christian faiths and those without any specific religious affiliation may lead to underpowered results for these subsets. The findings from this study suggest that religious affiliation is positively associated with anticipating a role for spirituality in pharmacy education. Future studies in larger samples of religious minorities would clarify these questions in those populations. Finally, work can be undertaken to evaluate longitudinal changes that occur in perceptions and spirituality by administering this survey instrument to graduating student pharmacists.

\section{CONCLUSION}

This study suggests that students entering the doctor of pharmacy program anticipate that spiritual aspects of patient care will encompass significant components of academic course work, and also will be integrated into professional practice settings. Further research is warranted to confirm these findings in a more geographically representative population and to determine the extent of spiritual aspects of patient care in pharmacy curriculums around the country.

\section{REFERENCES}

1. Ferrell B, Otis-Green S, Economou D. Spirituality in cancer care at the end of life. Cancer J. 2013;19(5):431-437.

2. Lucchetti G, Lucchetti AL, Puchalski CM. Spirituality in medical education: global reality? J Relig Health. 2012;51(1):3-19.

3. Nadarajah S, Berger AM, Thomas SA. Current status of spirituality in cardiac rehabilitation programs: a review of literature. J Cardiopulm Rehabil Prev. 2013;33(3):135-143.

4. Stewart WC, Adams MP, Stewart JA, Nelson LA. Review of clinical medicine and religious practice. J Relig Health. 2013; 52(1):91-106.

5. Koenig HG. Religion, spirituality, and medicine: research findings and implications for clinical practice. South Med J. 2004; 97(12):1194-1200.

6. American Medical Association. Contemporary Issues in Medicine: Communication in Medicine. Washington DC; 1999. 7. Puchalski CM, Larson DB. Developing curricula in spirituality and medicine. Acad Med. 1998;73(9):970-974.

8. Lucchetti G, Lucchetti ALG, Espinha DCM, de Oliveira LR, Leite JR, Koenig HG. Spirituality and health in the curricula of medical schools in Brazil. BMC Med Educ. 2012;12:78.

9. Giske T. How undergraduate nursing students learn to care for patients spiritually in clinical studies - a review of literature. $J$ Nurs Manag. 2012;20(8):1049-1057.

10. Cooper JB, Brock TP, Ives TJ. The spiritual aspect of patient care in the curricula of colleges of pharmacy. Am J Pharm Educ. 2003; 67(2): Article 44.

11. Dugan BD, Kyle JA, Kyle CW, Birnie C, Wahba W. Integrating spirituality in patient care: preparing students for the challenges ahead. Curr Pharm Teach Learn. 2011;3(4):260-266.

12. Campbell J, Blank K, Britton ML. Experiences with an elective in spirituality. Am J Pharm Educ. 2008;72(1):Article 16.

13. Underwood LG. The daily spiritual experience scale: overview and results. Religions. 2011;2(4):29-50.

14. Koenig HG, Büssing A. The Duke University religion index (DUREL): a five-item measure for use in epidemiological studies. Religions. 2010;1(1):78-85.

15. Underwood LG. Ordinary spiritual experience: qualitative research, interpretive guidelines, and population distribution for the daily spiritual experience scale. Arch Psychol Relig. 2006;28(1):181-218.

16. Rosenbaum CC. The role of the pharmacist - prayer and spirituality in healing. Ann Pharmacother. 2007;41(3):505-507. 17. Higginbotham AR, Marcy TR. Spiritual assessment: a new outlook on the pharmacist's role. Am J Health Syst Pharm 2006; 63(2):169-173.

18. Medina MS, Plaza CM, Stowe CD, et al. Center for the Advancement of Pharmacy Education 2013 educational outcomes. Am J Pharm Educ. 2013;77(8):Article 162.

19. Hammer DP, Berger BA, Beardsley RS, Easton MR. Student professionalism. Am J Pharm Educ. 2003;67(3):Article 96.

20. Evans E. An elective course in cultural competence for health care professionals. Am J Pharm Educ. 2006;70(3):Article 55.

21. Poirier TI, Butler LM, Devraj R, Gupchup GV, Santanello C, Lynch JC. A cultural competency course for pharmacy students. Am J Pharm Educ. 2009;73(5):Article 81.

22. Cooperman A. America's Changing Religious Landscape. Washington DC: Pew Research Center; 2015. 